\title{
Screening of Novel Inducer for D-amino Acid Oxidase by Trigonopsis variabilis
}

\author{
Neeraj Gupta, Ravi Kumar Gundampati, and Debnath M.
}

\begin{abstract}
Goal of present studies was the optimization of production media of $\mathrm{D}$-amino acid oxidase by Trigonopsis variabilis using one-at-a-time strategy \& screening of novel inducer. In different carbon and nitrogen sources, glucose and ammonium sulfate were found the best carbon and nitrogen source with 4:1 C: $N$ ratio. The best new inducers found were 3-(3, 4 -Dihydroxyphenyl) DL-alanine, DL- $\beta$ - Phenyl alanine, DL-2- Amino-n-butyric acid. Four fold of D-amino acid oxidase yield was observed when 3-(3, 4 -Dihydroxyphenyl) DL-alanine was used as inducer as compared with D-Ala. The optimum concentration of the best inducer 3-(3, 4 -Dihydroxyphenyl) DL-alanine, was $10 \mathrm{mM}$. High Induction effect was observed when inducer was added in media in 0 hour of fermentation.
\end{abstract}

Index Terms -D-Amino acid oxidase (DAAO), 3-(3, 4Dihydro -xyphenyl) DL-alanine, Trigonopsis variabilis

\section{INTRODUCTION}

D-Amino acid oxidase (DAAO, EC 1.4.3.3) is inducible flavoenzyme that catalyzes the oxidative deamination of D-amino acids (DAA) with a strict stereospecificity to give $\alpha$-keto acids and ammonia; $\mathrm{FADH}_{2}$ then reoxidizes by molecular oxygen, producing hydrogen peroxide. Due to broad substrate specificity and high steriospecificity of DAAOs, makes its demand high in several food \& pharmaceutical industries. For instance, production of $\alpha$-keto acids, which are valuable and useful therapeutic agent for the treatment of chronic uremia [1], separation of L-amino acids from racemic mixture of DL-amino acids, which is used as feed additives, components of infusion solutions, and starting materials for pharmaceuticals [2], in biosensor preparation for the detection of homocysteine in human plasma [3] \& most important application in pharmaceutical industries is conversion of cephalosporin $\mathrm{C}$ to7-aminocephalosporinic acid (7-ACA) [4] which is a key compound for the production of many semisynthetic $\beta$-lactam drugs (world market, \$20.5 3 109).

D- amino acid oxidase activity is widely distributed among organisms ranging from yeast to human; for example, they occur in vertebrates, especially mammals, and in microorganisms, such as the fungi Cephalosporium acremonium, Neurospora crassa Fusarium solani, and Fusarium oxysporum, the algae Chlorella vulgaris, the yeasts Candida tropicalis, Trigonopsis variabilis, and Rhodotorula gracilis, and the bacterium Alcaligenes denitrificans. Plants

Manuscript received April 18, 2012; revised May 31, 2012

The authors are with School of Biochemical Engineering, Institute of Technology, Banaras Hindu University, Varanasi-221005, India (e-mail: debnathmira@yahoo.co.in,neeraj.rs.bce@itbhu.ac.in) have no DAAO activity. Microbial DAAO enable it more suitable over human D- amino acid oxidase in biotechnological application due to its high turnover number, tight binding to its coenzyme and more of its gene expression [5]. Trigonopsis variabilis DAAO is only microorganism that's practical importance was reported.

The induction of DAAO by $T$. variabilis was studied using different DL-amino acid as well as unmetabolized inducer such as $N$-Carbamoyl-D-alanine, $N$-Acetyl-D-tryptophan, $N$-Chloroacetyl-D-aminobutyric acid [6]-[8].

However, the aim of our study was optimization of DAAO production by $T$. variabilis using different carbon, nitrogen sources, screening of new unmetabolizable inducer, and their effect on DAAO production during different time of fermentation process.

\section{MAterials AND METHODS}

\section{A. Microorganism \& Chemicals}

A strain of Trigonopsis variabilis (MTCC 1354) was obtained from Institute of Microbial Technology, Chandigarh, India. The substances tested as inducers were purchased from Hi-Media, laboratories, Mumbai, India. All other reagents used were of analytical grade.

\section{B. Culture Conditions}

T. variabilis was grown in $250 \mathrm{ml}$ conical flask in $30^{\circ} \mathrm{C}$ and $180 \mathrm{rpm}$ containing $1 \%$ of glucose, $0.5 \%$ of $\left(\mathrm{NH}_{4}\right)_{2} \mathrm{SO}_{4}$, $0.5 \%$ of $\mathrm{KH}_{2} \mathrm{PO}_{4}, \mathrm{MgSO}_{4} .7 \mathrm{H}_{2} \mathrm{O} 1 \mathrm{~g} /$ liter, $\mathrm{CaCl}_{2} 0.5 \mathrm{~g} /$ liter, $\mathrm{ZnSO}_{4} 60 \mathrm{mg} /$ liter, $\mathrm{FeSO}_{4} 40 \mathrm{mg} /$ liter, $\mathrm{MnSO}_{4} 40 \mathrm{mg} / \mathrm{liter}$, $\left(\mathrm{NH}_{4}\right)_{6} \mathrm{Mo}_{7} \mathrm{O}_{24} 40 \mathrm{mg} /$ liter, CuSO ${ }_{4} 40 \mathrm{mg} /$ liter, $\mathrm{H}_{3} \mathrm{BO}_{3} 100$ $\mathrm{mg} /$ liter, biotin $0.2 \mathrm{mg} /$ liter [6]. D-alanine or other amino acid derivatives were used as inducer $(10 \mathrm{mM})$. Glucose and other media composition were sterilized separately. All inducers were sterilized using membrane filter $(0.2 \mu \mathrm{m})$ separately.

\section{Preparation of the Cell Extract}

The cells were harvested by centrifugation at $20,000 \mathrm{~g}$ at $4^{\circ} \mathrm{C}$ for 15 minutes. Cell mass was suspended in potassium phosphate buffer ( $\mathrm{pH}$ 8.0) containing $2 \mathrm{mM}$ EDTA, $5 \mathrm{mM}$ 2-mercaptoethanol \& $0.1 \%(\mathrm{v} / \mathrm{v})$ Triton X-100 [9]. It was sonicated for cell wall lyses and supernatant was collected for determination of D-amino acid oxidase activity.

\section{Enzyme Assay}

The DAAO activity was estimated spectrophotometrically by performing a coupled enzyme test at $37^{\circ} \mathrm{C}$ in $0.19 \mathrm{mM}$ sodium pyrophosphate buffer $(\mathrm{pH} 8.3)$, in which D-alanine was used as the substrate[10]. One unit of enzyme activity is defined as the amount of enzyme oxidizing 1 micromole of 
D-alanine per minute at $25^{\circ} \mathrm{C}$ and $\mathrm{pH} 8.3$, in presence of catalase.

\section{RESULT AND DISCUSSION}

T. variabilis was used for DAAO production in submerged fermentation. Optimization of the fermentation medium was studied with a view to develop economically viable fermentation technology for DAAO production.

The optimization of fermentation parameter condition was done in one-at-a-time strategy to enhance the DAAO yield. Different monosaccharide and disaccharides were used as carbon sources such as glucose, fructose, galactose, sucrose, maltose, and lactose, to find the optimal fermentation media for DAAO production. For the maximal production of DAAO from T.variabilis, monosaccharides were found to be the most effective carbon source. In all different monosaccharides as carbon sources used, glucose was found to be the most suitable to induce the DAAO production. Glucose require no extra step for enter in glycolytic pathway comparison of other monosaccharides and disaccharides. Fig 1. shows the different carbon sources $(1 \%)$ studied in the fermentation medium for DAAO enzyme production.

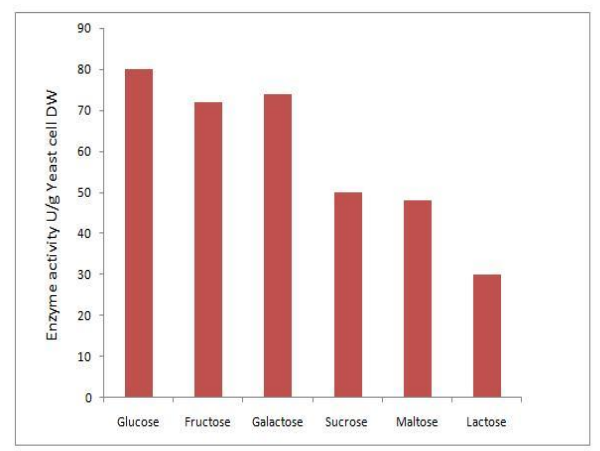

Fig. 1. Effect of different carbon sources on production of DAAO by $T$. variabilis.

Similarly various inorganic and organic nitrogen content sources were studied as shown in Fig 2. It was found that $\left(\mathrm{NH}_{4}\right)_{2} \mathrm{So}_{4}$ was chosen as the suitable best nitrogen source followed by yeast extract and urea for DAAO production.

C: $N$ value $4: 1$ was observed.

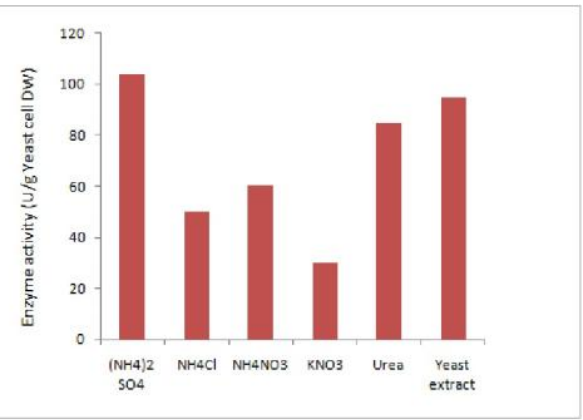

Fig. 2. Effect of different nitrogen sources on production of DAAO by $T$. variabilis.

The maximum enzyme production was studied at $\mathrm{pH}$ range of 4 to $10 \&$ temperature $26^{\circ} \mathrm{C}$ to $34^{\circ} \mathrm{C}$. $\mathrm{pH} 7 \&$ temperature $30^{\circ} \mathrm{C}$ was the best for maximum DAAO yield (Fig $3 \& 4$ ).



Fig. 3. Effect of different $\mathrm{pH}$ on production of DAAO by T. variabilis.

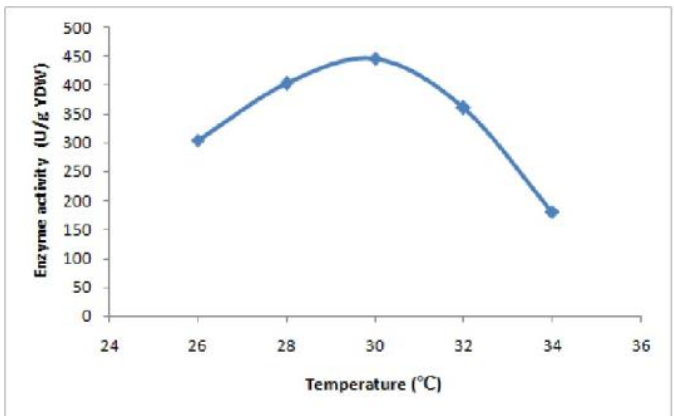

Fig. 4. Effect of different temperature on production of DAAO by $T$. variabilis.

Previously D- or DL-amino acids were simultaneously used as inducer and nitrogen source. Some unmetabolizable inducer such as $N$-Carbamoyl-D-alanine, $N$-Acetyl-Dtryptophan, $\mathrm{N}$-Chloro acetyl -D- aminobutyric acid were also reported as inducer [6]- [8].

In this paper three novel unmetabolizable inducers (3-(3, 4 -Dihydroxyphenyl) DL-alanine, DL- $\beta$ - Phenyl alanine, DL-2Amino-n-butyric acid) were studied. The most effective inducer was 3-(3, 4 -Dihydroxyphenyl) DL-alanine as 455 Units/g YDW DAAO yield (Table I).

TABLE I: SCREENING OF INDUCERS FOR DAAO PRODUCTION BY $T$. VARIABILIS

\begin{tabular}{|c|c|c|}
\hline Inducer* & $\begin{array}{c}\text { YDW } \\
\text { (g/liter) }\end{array}$ & $\begin{array}{l}\text { DAAO activity } \\
\text { (Units/g YDW) }\end{array}$ \\
\hline Without inducer & 6 & 34 \\
\hline D-Alanine & 5.8 & 112 \\
\hline DL- $\beta$ - Phenyl alanine & 5.2 & 122 \\
\hline DL-2- Amino-n-butyric acid & 5.4 & 95 \\
\hline $\begin{array}{l}\text { 3-(3,4 -Dihydroxyphenyl) } \\
\text { DL-alanine }\end{array}$ & 5 & 455 \\
\hline
\end{tabular}

*Each inducer was tested at a concentration of $10 \mathrm{mM}$

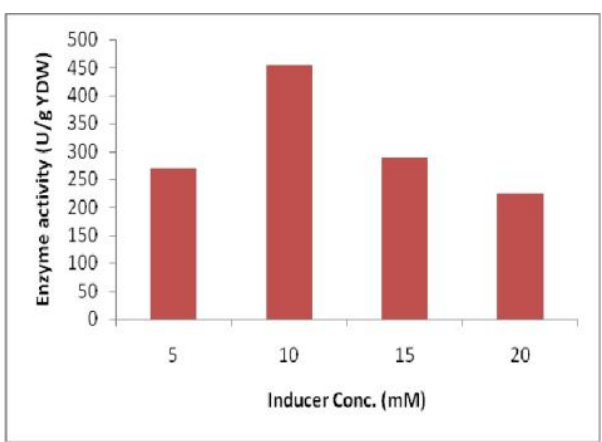

Fig. 5. Effect of different concentration of 3-(3, 4 -Dihydroxyphenyl) DL-alanine on production of DAAO by $T$. variabilis 
Optimization of 3-(3, 4 -Dihydroxyphenyl) DL-alanine concentration was studied at range of $5 \mathrm{mM}$ to $20 \mathrm{mM}$. 10 $\mathrm{mM}$ concentration of 3-(3, 4 -Dihydroxyphenyl) DL-alanine was optimum for high DAAO yield. High concentration of 3-(3, 4 -Dihydroxyphenyl) DL-alanine do not show significant effect on DAAO production and it may inhibit the growth of Trigonopsis variabilis.

Effect of inducer at different fermentation time was also studied. Addition of inducer at 0 hour of fermentation shows potent effect of DAAO yield. Fig. 6 .

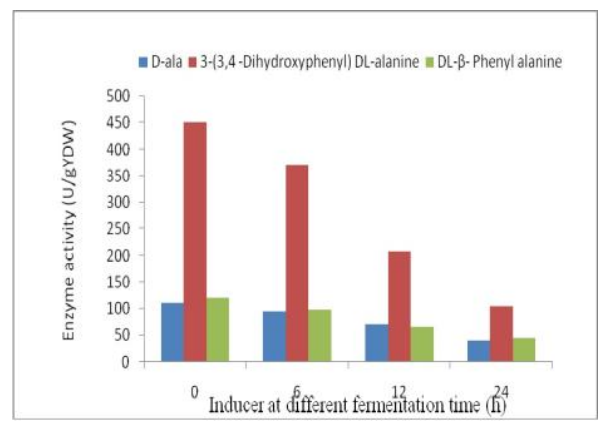

Fig. 6. Effect of Inducer on DAAO production during different fermentation time.

\section{ACKNOWLEDGMENT}

The authors are thankful to the University Grants Commission (UGC) for financial supports and to the School of Biochemical Engineering, Institute of Technology, BHU, Varanasi, India for providing laboratory and technical support.

\section{REFERENCES}

[1] M. M. Walser, "Principal of keto acid therapy in uremia," Am. J. Clin. Nutrition, vol. 31, pp. 1756-1760, 1978.

[2] E. M. Trost and L. Fischer, "Minimization of by-product formation during d-amino acid oxidase catalyzed racemate resolution of d/l-amino acids," J. Mol. Catal. B: Enzym, vol. 19/20, pp.189-195, 2002.

[3] G. Zhang, D. Liu, S. Shuang, and M. M. Choi, "A homocysteine biosensor with eggshell membrane as an enzyme immobilization platform," Sensors and Actuators B, vol. 114, pp. 936-942, 2006.

[4] S. V. Khoronenkova and V. I. Tishkov, "D-amino acid oxidase: physiological role and applications," Biochemistry (Moscow), vol. 73, pp. 1511-1518, 2008.

[5] L. Pollegioni, G. Molla, S. Sacchi, E. Rosini, R. Verga, and M. S. Pilone, "Properties and applications of microbial D-amino acid oxidase: current state and perspectives, Appl. Microbiol. Biotechnol, vol. 78 , pp. $1-16,2008$

[6] P. Singh, S. S. Marwaha, and N. Verma, "Role of Amino Acids in Production of $D$-amino Acid Oxidase, The Journal of Microbiology, vol. 39, pp. 229-231, 2001.

[7] K. Pranz, E. M., and M. Rohr, "Formation of D-amino acid oxidase in the yeast Trigonopsis variabilis," Can. J. Microbiol, vol. 31, pp. 625-628, 1985.

[8] R. Horner, F. Wagner, and L. Fischer, "Induction of the D-Amino Acid Oxidase from Trigonopsis variabilis," Appl. And Environmental Microbiol, vol. 62, pp. 2106-2110, 1996.

[9] Y. H. Lee, W. S. Chu, and W. H. Hsu, "Bioconversion of cephalosporin $\mathrm{C}$ with D-amino acid oxidase from the yeast Rhodosporidum toruloides," Biotechnology Letters, vol. 16, pp. 467-472, 1994.

[10] Y. Nagata, T. Shimojo, and T. Akino, "two spectrophotometric assays for D-amino acid oxidase: for the study of distribution patterns," Int $J$ Biochem, vol. 20, pp. 1235-1238, 1988. 